\title{
Challenging the Validity of Membership of the House of Representatives in Jordan
}

\author{
Laith K. Nasrawin
}

\begin{abstract}
This chapter aims to analyze the legal means available to challenge the validity of membership in the Jordanian House of Representatives, which is considered as one face of electoral disputes that arise after the completion of the voting process and the announcement of final results. The chapter focuses on the scrutiny that the Jordanian judiciary exercises in case of contesting the election procedures and consequently claiming that the membership of a certain candidate is void, from the legitimacy and constitutionality perspectives. The oversight of legitimacy revolves around the extent to which electoral procedures were violated, whereas the constitutional control relates to the extent the Law of Election is compatible with or contravenes the provisions of the Jordanian Constitution. Both methods were substantially revised in 2011, upon the comprehensive constitutional reform that Jordan conducted. Finally, the chapter deals with the legal implications of applying both the legitimacy and constitutional scrutiny with respect to the membership of those elected to the Jordanian House of Representatives.
\end{abstract}

\section{Introduction}

The right to elect is deemed as the most prominent manifestation of the participation of people in the decision-making process. In a parliamentary governmental system, the role of voters is limited to the selection of representatives to exercise the powers on their behalf, through the conduct of a fair and free election. As such, the Jordanian Constitution provides for various safeguards which ensure that voters are able to cast their votes first, and then to challenge the outcome of the election using all legal methods available. The reasons for challenge are either that the electoral proceedings were not correctly applied by the authority in charge, or that the rules for election contradict with the provisions of the Constitution. 
In this regard, Article 67.1 of the Jordanian Constitution clearly provides for the principles which should govern the holding of parliamentary elections in Jordan. It states that

"The House of Representatives shall be composed of members elected by general, secret and direct election in accordance with an election law which shall ensure the following matters and principles: The right of candidates to observe the electoral process, the punishment of those adversely influencing the voters' will, and the integrity of the electoral process in all of its stages".

A further safeguard for holding a fair and free election was incorporated by the revision of the Jordanian Constitution in 2011: an Independent Election Commission (IEC) was to be set up by law to supervise the parliamentary electoral process and to administer it in all of its stages. When established in 2012, the jurisdiction to hold parliamentary elections was moved from the Ministry of Interior to the IEC in accordance with the Constitution. This has helped to restore public confidence in the parliamentary representation system, and has worked to increase voters' participation in parliamentary elections held after 2012.

The importance of holding fair and free parliamentary elections also stems from the fact that Jordan is a signatory state to the main international instruments which form the International Human Rights Law. Both the Universal Declaration of Human Rights and the International Covenants on Civil and Political Rights provide for the international standards and norms for a fair and just election, which Member States must obey. Therefore, Jordan is under an international duty to comply with the principles stated by international law. Jordan is expected to uphold electoral justice, and to allow electorates the right to challenge before the judiciary, key decisions related to all stages of the electoral process; starting from the preparation of voters' lists, to deciding on candidacy applications, and finishing with challenging final results published in the Official Gazette from any party with interest, and as per the procedures described in the Constitution.

In this chapter, all procedures relating to the submission of appeals against the validity of parliamentary membership are covered in terms of the methods for challenging the illegality or the constitutionality of the membership of one of the elected candidates of the House of Representatives in Jordan, and in terms of the implications in case a challenge is upheld. 


\section{Challenging the legitimacy of membership of the Jordanian Parliament}

This legal path of challenging the validity of membership for those elected to the House of Representatives in Jordan aims to verify as to whether the general election was conducted in accordance with the provisions of the electoral law. In this regard, the 2011 constitutional amendments have fundamentally changed the proceedings in question. Before 2011, challenges by the electorate claiming that elections were held in violation of the statutory provisions used to be submitted to the House of Representatives itself. The repealed Article 71 of the Jordanian Constitution provided that

"The House of Representatives shall have the right to determine the validity of the election of its members. Any voter shall have the right to present a petition to the Secretariat of the House within fifteen days of the announcement of the results of the election in his constituency setting out the legal grounds for invalidating the election of any deputy. No election may be considered invalid unless it has been declared as such by a majority of two-thirds of the members of the House".

It was argued that the above-mentioned mechanism was in full contradiction with the international standards for the right of adjudication and access to justice. It was also regarded as a clear contravention of the principle that individuals must have access to natural justice as per the international conventions. ${ }^{1}$ Furthermore, challenging parliamentary membership to the House of Representatives was seen as a serious trespass on the ultimate jurisdiction of the judiciary to resolve disputes. Article 102 of the Jordanian Constitution provides that "The Civil Courts in the Hashemite Kingdom of Jordan shall have jurisdiction over all persons in all matters, civil and criminal, including cases brought by or against the Government".

Moreover, this regulation, authorizing the House of Representatives with the constitutional power to decide on the petitions disputing the validity of membership of one or more of its members, was seen as entirely against the principles of fairness and objectivity; Parliament is not a judicial body, and was deemed as the opposition and the jury at the same time. As such, and despite the numbers of challenges submitted after every

1 Laith Nasrawin, "The Constitutional Amendments of 2011 and their impact on the public authorities in Jordan." University of Jordan Journal of Shari'a and Law Sciences, DIRASAT 40, 2013: pp 223.240. 
general election held in Jordan, the House of Representatives had accepted none since the promulgation of the Jordanian Constitution in $1951 .^{2}$

This mechanism was altered in 2011, and the judiciary has been assigned the responsibility to adjudicate on challenges concerning the validity of membership to the House of Representatives. Article 71 of the Jordanian Constitution was amended to the effect that the judiciary was given the competence to determine the validity of the election of the Members of the House of Representatives. Since 2011, every voter has the right to file a petition to the Court of Appeal, which has jurisdiction over the constituency of the representative the validity of whose election is contested from his constituency. This has to be done within fifteen days from the date of the publication of the elections results in the Official Gazette. $^{3}$ The petition should include clear reasons, and a decision by the Court of Appeal must be issued within thirty day from the date of the registration of the petition. Such judicial decision shall be final, and is not subject to any way of challenge.

It could be argued in this context that it would have been better to give the constitutional power to resolve electoral disputes to the administrative judiciary. Administrative courts are better suited and thus be more capable to apply the principles of public law, which govern the relationship between individual and the state when the latter is having the sovereignty and the authority. ${ }^{4}$ Furthermore, the administrative judiciary in Jordan consists of a two-tier system as decided in the 2011 constitutional amendments. As such, judgments issued by the Administrative Court are challengeable to the High Administrative Court. Also, giving the jurisdiction to the administrative courts to adjudicate electoral appeals would unify court principles and jurisprudence. There are concerns that the existing of three courts of appeal in Jordan would lead to various interpretations and understandings of the legal rules relating to the resolving of disputes in question.

2 Eid Al-Husban, "Political and Judicial Safeguards for the Right to Elect in Accordance with the Provisional Election Law for the House of Representatives No. (34) of the year 2001.” Manarah Journal for Researches and Studies 9, 2003: 325.

3 Sayeed Al-Harbi, "Electoral Disputes and Resolving Challenges of Validity of Parliamentary Membership”. (LLM Thesis submitted to Al al-bayt University, 2005): 51.

4 Laith Nasrawin, "Political and Judicial Safeguards for the Right to Elect in Accordance with the Provisional Election Law for the House of Representatives No. (34) of the year 2001". 
The Constitution of Jordan has made the judicial decision issued by the Court of Appeal ruling on the validity of the parliamentary membership final and not subject to any means of reconsideration. ${ }^{5}$ This constitutes a clear denial of justice, and contravenes the right of access to all types and level of courts. The same critics about the constitutional provision before the 2011 amendments, which provided that decisions by the House of Representatives regarding petitions presented by electorates were final, could be brought forward against the revised constitutional provision which authorizes the Court of Appeal to adjudicate challenges against the validity of membership in Parliament.

The importance of appealing against the decisions of the Court of Appeal stems from the powers granted to the Court to declare the entire election in one constituency void. If it is evident to the Court that the election procedures in the constituency to which the petition relates are not consistent with the provisions of the election law, it can rule for the invalidation of the whole election in that constituency.

The legal implication of such ruling goes beyond the two parties to the challenge, over to other elected members, who are going to lose their seats in Parliament as a result of the Court's decision. Thus, they should be allowed the right to challenge the decision in question issued by the Court of Appeal to a higher judicial body. ${ }^{6}$

Once the challenge is submitted to the Court of Appeal, the Court shall resolve to dismiss the petition and, accordingly, the parliamentary seat is confirmed to the elected member in question. The Court of Appeal may also decide to uphold the petition, and in such case, it shall announce the name of the successful representative, and the successor to the Member of Parliament whose membership was invalidated. The House of Representatives is required to abide by the court decision. It is expected to declare the invalidity of the membership of the representative concerned and to invite the new member specified by the Court's decision to take the oath immediately.

In order to ensure the stability and continuity of the work of Parliament with respect to enacting legislation and monitoring acts of government, it has been decided in the Jordanian Constitution that all actions taken by

5 Nofan Kin'an, The Principles of Constitutional Law and the Jordanian Constitutional System. Amman: Dar Ithraa, 2013: 3, 29.

6 Laith Nasrawin, "Political and Judicial Safeguards for the Right to Elect in Accordance with the Provisional Election Law for the House of Representatives No. (34) of the year 2001”. 
the member whose membership was invalidated by the Court of Appeal prior to its invalidation are deemed correct.

\section{Challenging the constitutionality of membership of the Jordanian Parliament}

Beside the right to challenge the validity of membership to the Court of Appeal, any interested party may contest the constitutionality of the election law in full or any of its provisions. Any decision declaring the said law or any of its rules unconstitutional would make the election process void, and as such invalidating the memberships of all elected candidates to the House of Representatives.

It is submitted that constitutional judicial review provides a valuable avenue for advancing human rights and access to justice. Depending on how constitutional adjudication is structured in a given country, it can be used to nullify or amend laws and regulations which are incompatible with individual rights and freedoms enshrined in national constitutions and international treaties. Also, constitutional judicial review is an example of the functioning of separation of powers in a modern governmental system where the judiciary is one of three branches of government. ${ }^{7}$ In essence, it allows the judiciary to take an active role in ensuring that the other branches of government abide by the constitution.

In Regina v. Secretary of State for the Home Department, Ex parte Pierson $[1998],{ }^{8}$ Lord Steyn affirmed that the importance of constitutional review stems from the fact that it includes both procedural and substantive elements, and thus is probably best described as reflecting a version of the "thick" understanding of the rule of law.

As part of the constitutional revision of 2011, a new chapter (Chapter 8 ) was added to the Jordanian Constitution which created a Constitutional Court to work as an independent and separate judicial body with headquarters in the capital. The Constitution provides for the establishment of an ordinary law that defines the work and procedures within the new Court; the Law of the Constitutional Court of Jordan was issued in 2012, which was highly influenced by the French model of constitutional review and, to some extent, by other regional systems in Egypt and Bahrain. ${ }^{9}$

7 Ali Shadnaw, The Jordanian Constitutional System. Amman: Dar Wa'el, 2013.

8 [1998] AC 539, 591.

9 Nu'man Al-Khateeb, Al-Baseet in the Constitutional System Amman: Dar Althaqafa, 2014. 
It should be noted that Jordan had always applied the constitutional judicial review prior to the constitutional amendments of 2011 which led to the establishment of the Constitutional Court. However, its scope was unclear; neither the Constitution nor any laws or regulations gave judges an explicit power to conduct such a review. Judges of all courts had assumed that function as a part of their duty to decide on the cases before them for the sake of safeguarding the individual rights and liberties guaranteed by the Constitution. ${ }^{10}$ They had no ability to declare laws or regulations null and void, but they could refrain from applying laws that they found unconstitutional in pending cases, even if the issue of non-constitutionality had not been raised by the parties, and these decisions did not carry precedential value. ${ }^{11}$

Nevertheless, with the establishment of the Constitutional Court in Jordan, an independent judicial body was constitutionally assigned with the power to strike down laws and regulations which are considered unconstitutional, and to issue judgments which are deemed final and binding on all authorities and individuals of the state.

For the sake of ensuring a high standard of effectiveness in the work of the Constitutional Court, and to avoid stressing the judges with illfounded claims of unconstitutionality, access to the Court was strictly drawn through two main avenues, political and judicial. Political access is given through the constitutional right of the House of Representatives, the House of Senate, and the Council of Ministers to directly submit challenges against certain provisions in a law or regulation in effect that they consider to contravene the Constitution, and to request the court to determine its constitutionality. The Constitutional Court is expected to resolve the petition no later than 120 days from the day of receipt by the Court.

As far as individuals and political parties are concerned, they have the right to submit challenges of unconstitutionality but in an indirect way. The Constitutional Court Law allows any of the parties to a case pending before the courts to put forward the defense of unconstitutionality of any law or regulation that is applicable to the substance of the case. If such defense is deemed substantive and serious by the court considering the case,

10 Ali Abu Hjaileh, Scrutinizing the constitutionality of laws in Jordan. Amman: Commercial Dastour Press, 2004: 123-125.

11 M. Abu Karaki, R. S. Faqir, and M. Marashdah, "Democracy and judicial controlling in Jordan: A constitutional study." Journal of Politics and Law 187, 2011: 180195. 
it shall then refer it to the Court of Cassation for further consideration as to be referred to the Constitutional Court. ${ }^{12}$

Thus, the mechanism of applying the constitutional judicial review to challenge the validity of membership in the House of Representatives requires that a case involving the application of the election law or any of its provisions is filed before a national court. The applicant can then submit the defense of unconstitutionality of the said law. The Law of the Constitutional Court requires that such defense is put before the court that is considering the case by means of a memorandum, in which the challenger shall state the name and number of the law or regulation in respect of which the defense of unconstitutionality has been raised. The challenger must also define the scope of the defense in a clear and specific manner with support for its claim that such law or regulation is applicable to the substance of the case, with the grounds for why it is in breach of the Constitution.

If the court considering the case finds that the election law or any of its provisions in respect of which the defense of unconstitutionality has been raised is applicable to the substance of the case and that the defense of unconstitutionality is substantive, it shall suspend consideration of the case, and refer the defense to the Court of Cassation to decide on the issue of its referral to the Constitutional Court. The underlying case must remain suspended until the constitutionality claim is either rejected by the Cassation Court or resolved by the Constitutional Court.

According to the Law of the Constitutional Court, the Court of Cassation shall convene with a panel of at least three members, and it shall issue its decision within 30 days from the date the case reaches it. If it approves the referral, it shall notify the parties to the case to that effect.

If the constitutionality challenge is put before the Court of Cassation or the High Administrative Court for the first time, the respective court must immediately decide on the issue of referring the challenge to the Constitutional Court in accordance with the Constitutional Court Law.

Arguments have been made against the referral system in Jordan, contending that denying individuals the right to file constitutional challenges directly with the Constitutional Court compromises their right to free access to the court. ${ }^{13}$ It was also argued that direct access to constitutional

12 Laith Nasrawin, "Protecting Human Rights Through Constitutional Adjudication: Jordan as a Case Study.” Digest of Middle East Studies 25: 264-284.

13 Mohammed Hammouri, Rights and Freedoms between Political Whims \& Constitutional requisites. Amman: Dar Wa'el, 2010. 
judicial review would provide individuals and groups with more opportunities to submit challenges of unconstitutionality that would allow the Constitutional Court to fill any gaps in the existing legal system that would otherwise leave - without remedy - those affected by alleged unconstitutional legislation. ${ }^{14}$

This argument should be dismissed. Giving a complainant a direct access claim would overburden the Constitutional Court and restrict its efficiency. Having a filtering system of unconstitutional claims in Jordan is in line with international best practices that give Constitutional Courts the right to have a broad discretion to dispose of complaints according to clearly stated criteria like those deployed elsewhere. In Germany, for instance, the constitutional complaint may not be lodged until all remedies have been exhausted, however, it may decide immediately on a complaint of unconstitutionality lodged before all remedies have been exhausted if it is of general relevance or if recourse to other courts first would entail a serious and unavoidable disadvantage for the complainant pursuant to Article 90.2 of the Law on the Federal Constitutional Court. ${ }^{15}$

Another example is the U.S. Supreme Court, which also controls its own docket. It has wide latitude to decide which cases to hear, and denies about $99 \%$ of certiorari (a writ or order by which a higher court reviews a decision of a lower court) petitions. Even though the court receives about 10,000 civil and criminal petitions per year, it has established an efficient vetting process which allows the court to identify about $75-80$ cases that warrant an oral argument. ${ }^{16}$

In France, access to the French Constitutional Council is restricted to raising the question of unconstitutionality within an existing case in another court, and to applying a test of seriousness to complaints of unconstitutionality. ${ }^{17}$ Complaints reach the Constitutional Council only if the highest civil or administrative court has approved the referral. In Egypt, a litigant has the right to file a claim directly with the Supreme

14 Ahmad Mitwali, Constitutional Law and Political Systems. Alexandria: Maarif Press, 1993: 195.

15 Laith Nasrawin, "Protecting Human Rights Through Constitutional Adjudication - Jordan as a Case Study". 2016.

16 R. C. Black and C. L. Boyd, "Selecting the Select Few: The Discuss List and the U.S. Supreme Court's Agenda-Setting Process.” Social Science Quarterly 94.4, 2012: 1124-1144.

17 M. Tushnet and Fleiner, Routledge Handbook of Constitutional Law. Abingdon, UK: Routledge Press, 2013. 
Constitutional Court when the ordinary court adjudicating his or her case has determined that the constitutional matter is serious. ${ }^{18}$

However, the multi-referral system of challenges to the Constitutional Court in Jordan raises concerns as whether ordinary judges can refer a case to the Cassation Court without being prompted by a litigant. ${ }^{19}$ The answer to this question is not definite and can be subject to two different views. It was argued that each judge has a duty to ensure that only laws that conform to the Constitution are applied in cases before them, and that they have not only a right, but an obligation to refer constitutionality issues sent to them be sent to the Constitutional Court. ${ }^{20}$ Others argue the opposite that the current Constitutional Court Law requires a motion from a party to a lawsuit in order to apply the multi-referral system. ${ }^{21}$

As far as the definition of substance and seriousness of the challenge of unconstitutionality is concerned, it was submitted that this term is a purely technical matter of whether the outcome in the underlying case depends on the constitutionality of the challenged provision; a case at hand cannot be justly adjudicated without determining constitutionality of a particular legal provision. ${ }^{22}$ Seriousness also refers to the importance of the challenged law or regulation to the case at hand. It is a concept related to public interest and human rights: a judge must take into account socio-political and economic implications of a challenged law and determine if the law is compatible with fundamental rights and freedoms outlined in the constitution.

International experience suggests that the term "serious" should be understood as "not frivolous". Accordingly, complaints of unconstitutionality should reach the Constitutional Court whenever the challenged law is relevant to the case and the argument against constitutionality could be made by a reasonable person in good faith, not just as a delaying tactic. ${ }^{23}$

18 N. Kamel, Judicial Scrutiny on Constitutionality of Laws: Constitutional Adjudication. Cairo: Dar Alnahda, 1993.

19 Laith Nasrawin, "Protecting Human Rights Through Constitutional Adjudication: Jordan as a Case Study", 2016.

20 A. Salman, Systems of Scrutinizing Laws: Comparative Study between Different Legal Systems and the Egyptian Law. Cairo: Dar Sa'ed Samak for Legal and Economic Publications, 2000: 174.

21 R. Al-sha'er, General Theory of Constitutional Law. Cairo: Dar Alnahda Alarabieh, 2005.

22 A. Al-Bazz, Scrutinizing the Constitutionality of Laws in Egypt. Alexandria: Egyptian Universities Press, 1978: 556.

23 S. Fawzi, The Constitutional Lawsuit. Cairo: Dar Alnahda Aljaditha, 1993: 92. 
On a national level, it is desirable that the Constitutional Court issues guidelines or instructions on when claims of unconstitutionality are serious and therefore warrant referral by lower courts and the Court of Cassation. Also, all courts in Jordan should publish well-reasoned decisions so that the referral practices can be harmonized and made consistent. This is especially important at this early stage in the Constitutional Court's life, a stage at which shared understandings of how the system will work are still developing.

Any judgment of the Constitutional Court with regard to a challenge of unconstitutionality of the election law is final and binding on all authorities and the people. Generally speaking, any judgment issued by the Constitutional Court shall be enforceable with immediate effect. Thus, if the Constitutional Court rules that a law or regulation in force is unconstitutional, the law or regulation shall be deemed void from the date the judgment is issued. However, if the judgment specifies another date for its enforceability, the law or regulation shall be deemed void from the date specified in the judgment.

By applying the above-mentioned principles on any constitutional challenge of the election law, once the Constitutional Court rules that the said law or any of its provisions is unconstitutional, the electoral process shall then be deemed void from the date the judgment is issued, and accordingly, all memberships of elected candidates are considered null and void.

\section{Conclusion}

The Jordanian legal system provides for two means of challenging the validity of membership of the House of Representatives. One challenge that the electoral process, at any stage, has violated the election law, known as the legitimacy submission, and the second petition is that the election law - or any of its provisions - contradicts with the Constitution, known as the constitutionality submission.

The Constitution of Jordan was amended in 2011 and statutory rules of both ways were revised. The legitimacy challenge is not any more submitted to the House of Representatives itself, but to the Court of Appeal where the doctrine of access to natural justice is preserved. The administrative judiciary, however, could be seen as a more suitable court, giving the nature of the challenge of membership that principles governing public law are applicable. 
The Court of Appeal is given the power to invalidate the membership of the elected candidate in question, and it is also empowered with the right to declare the electoral process in one constituency as a whole to be void.

As per the constitutional submission, a new Constitutional Court was established in Jordan in 2012 in the hope that it would serve as an effective judicial tool to protect human rights, enhance access to justice, and advance the rule of law. It was set up as a response to public demands, with powers to invalidate laws and regulations that contradict the Constitution and violate fundamental rights and freedoms. However, skeptics argued that the constitutional review process was unnecessarily cumbersome, that many provisions of the Constitutional Court Law are vague and ambiguous, and that the lack of direct access to the Court makes it difficult for individuals and civil society to use constitutional judicial review in an effective and productive manner.

Challenges of unconstitutionality against the election law could be submitted directly to the Constitutional Court by both Chambers of Parliament and the Council of Ministries. Meanwhile, individuals must go through the system of "multi-referral", starting from the court considering the case to the Court of Cassation before being taken up to the Constitutional Court. Any decision by the Constitutional Court declaring the election law or any of its rules to be against the Constitution would imply that memberships of all those elected are null and void. 